\title{
The Effectiveness Of A Concrete Media Assisted Project Based Learning Model On Students 'Science Competency
}

\author{
Ni Wayan Aprillia Pratiwi \\ Fakultas Ilmu Pendidikan, Universitas Pendidikan Ganesha, Singaraja, Indonesia \\ email: apriliapratiwi727@gmail.com
}

Ida Bagus Surya Manuaba

Fakultas Ilmu Pendidikan, Universitas Pendidikan Ganesha, Singaraja, Indonesia email: idabagussurya.manuaba@undiksha.ac.id

\section{A R T I C L E I N F O Article history: \\ 1 Agustus 2020 Received in revised form \\ 20 September 2020 \\ Accepted 10 November 2020 \\ Available online 20 \\ November 2020 \\ Kata Kunci: \\ Project Based Learning, \\ media konkret, IPA \\ Keywords: \\ Project Based Learning, \\ concrete media, science.}

\begin{abstract}
A B S T R A K
Penelitian ini bertujuan untuk mengetahui pengaruh Model Project Based Learning berbantuan media konkret terhadap kompetensi pengetahuan IPA Siswa kelas V SD. Eksperimen semu digunakan dalam penelitian ini dengan desain nonequivalent control group desain. Jumlah seluruh siswa kelas V SD Tahun 2019/2020 sebanyak 13 kelas terdiri dari 371 siswa yang dijadikan sebagai populasi penelitian. Random sampling digunakan untuk memilih sampel. Kelompok eksperimen dalam penelitian ini adalah kelas VB dengan jumlah 32 siswa dan kelompok kontrol kelas VA dengan jumlah 33 siswa. Data kompetensi pengetahuan IPA dikumpulkan menggunakan instrumen tes objektif dalam bentuk pilihan ganda berjumlah 31 butir soal yang telah divalidasi. Data kompetensi pengetahuan IPA selanjutnya dianalisis menggunakan uji t polled varian. Berdasarkan hasil analisis uji $\mathrm{t}$ diperoleh thitung $=4,17$. Nilai tersebut kemudian dibandingkan dengan nilai ttabel dengan $\mathrm{dk}=63$. Dengan taraf signifikansi $5 \%$ sehingga diperoleh nilai ttabel $=2,000$ berarti Ho ditolak, karena thitung $=4,17>$ ttabel $=2,000$. Demikian pula rata-rata kompetensi pengetahuan IPA siswa kelompok eksperimen $\mathrm{x}^{-}=81,43>\mathrm{x}^{-}=70,33$ rata-rata kompetensi pengetahuan IPA siswa kelompok kontrol. Kesimpulan yang didapat dari penelitian ini adalah model Project Based Learning berbantuan media konkret berpengaruh secara signifikan terhadap kompetensi
\end{abstract}

pengetahuan IPA siswa kelas V SD.

\begin{abstract}
A B S T R A C T
This study aimed to determine the effect of project based learning model assisted by concrete media toward the competency of science among students grade V SD Academic year 2019/2020. A quasi-experiment was used in this study with the nonequivalent control group design. The total number of students in grade V SD Academic Year 2019/2020 was 13 classes consisting of 371 students used as the study population. Random sampling was used to select the samples. The experimental group in this study was the grade VB with 32 students, and the control group was students grade VA with 33 students. Data of science knowledge competency was collected using an objective test instrument in multiple-choice totaling 31 items validated. The science competency data was then analyzed by performing the variant polled t-test. Based on the results of the $\mathrm{t}$-test, tcount $=4.17$. The score was then compared with the score of table with $\mathrm{df}=63$. With a significance level of $5 \%$ so that the score of table $=2,000$ means that Ho was rejected, because tcount $=4.17>$ ttable $=2,000$. Similarly, the average science competency among students in the experimental group $\mathrm{x}^{-}=81.43>\mathrm{x}^{-}=70.33$ the average of scientific competence of the control group students. The conclusion obtained from this study is that the Project Based Learning model assisted by concrete media significantly influences students' scientific competence grade V SD Academic Year 2019/2020.
\end{abstract}

\section{Introduction}

One of the subjects obtained by elementary school children in science is the science of natural phenomena, which is poured in the form of facts, concepts, principles, and laws that have been verified and through various activities in the scientific method. (Suwitri et al., 2013). Science is the mastery of a collection of knowledge in the form of facts, concepts, or principles and a process of discovery. (Panjaitan, 2017). Science is expected to be a vehicle for students to learn about themselves and their surroundings and prospects for development in everyday life (Adnyani et al., 2020). Ideally, the science learning process in elementary school provides opportunities for students to be actively involved in the learning process through real learning activities that can foster students' curiosity and scientific attitudes (Purwandari et al., 2014).

Given that it is so important to learn science, teachers need to continue to evaluate the learning process that is carried out continuously, such as using learning models that are following the material to be taught so that 
learning is more meaningful. Students' science knowledge competence increases at least achieving minimal completeness (KKM) (Rizwan, 2016). Science knowledge competence is a description of a student's ability through observation. It is measured from the cognitive aspect after going through training to be accounted for in understanding science lessons' content. The content of science lessons in elementary schools is expected to provide opportunities and increase student interest related to nature. Besides that, it will also make students more active in class with their groups so that the ability to communicate between students increases, because the role of science is so important for students, science should be mastered and become a fun subject for students so that students are more enthusiastic in participating in learning (Bahari et al., 2018; Samatowa, 2016).

However, low learning outcomes are the content of science lessons. The observations made show that cooperation between students and students is also less well-established because students are more likely to work alone than collaborate with others (Raharjo \& Kristin, 2019). Science is a difficult subject for students to understand. The limitations of learning media make students less understand science material, so many students have not reached the minimum completeness score. (Tarwiti, 2018). Based on the information submitted by the principal and fifth-grade teachers at SD Gugus I South Kuta for the 2019/2020 school year, the learning process in the classroom, especially the integration of science-filled lessons, has not been implemented properly, and the ability of students to construct basic knowledge possessed by the new ideas they have and the lack of ability to communicate when learning takes place so that it affects students' Natural Science Competencies. The learning process by applying models and learning media that tends to be monotonous also results in less meaningful learning from the learning received. To overcome this, an innovative learning model is needed.

One innovative learning model that can be used is a project based learning model. The Project Based Learning (PjBL) model requires students' skills in arranging activity in the learning process that can make students investigate independently. In its implementation, the teacher continues to monitor students' development in learning activities in the classroom (Trianto, 2010). With Project Based Learning students can learn independently and be directly involved who play an active role in solving problems (Sukawirya et al., 2017; Triningsih \& Mawardi, 2020). Project-Based learning is a learning method that uses a learning medium and is assessed following government regulations. Students must carry out exploration, assessment, interpretation, synthesis, and information to produce various learning outcomes (Pratama \& Prastyaningrum, 2016). Educators only act as facilitators. The focus of the PjBL model lies in student activities to unify learning resources and use them in realizing useful things but still following the curriculum set by the teacher, inviting students to explore and carry out evaluations so that they get results that are in line with expectations based on facts in the field (Hosnan, 2014; Kosasih, 2014). The implementation of this model begins with a problem, and students collaborate on sources of knowledge to solve existing problems. The PjBL model makes student-centred learning and activities carried out by collaborating with groups to complete projects according to the design that has been made at the design stage (Jagantara, 2014). The Project Based Learning model invites students to make decisions, find solutions to a problem, and practice a responsible attitude towards something that must be done (Anggreni et al., 2020). The benefits obtained from using this model result in students studying the learning resources obtained and pour their creativity into a work that is following the material received (Kristiyanto, 2020). The project-based learning model involves doing a project using information obtained and useful for their lives, which still refers to the curriculum's basic competencies. In its implementation, the Project Based Learning model can be assisted by concrete media.

Concrete media is a learning resource that specifically displays real objects in terms of size, sound, movements, surfaces, weights and their benefits to facilitate the learning process (Suwitri et al., 2013). The use of concrete media is believed to help teachers convey learning messages easily so that students can master these learning messages quickly and accurately (Siti \& Wardani, 2017). With concrete media, students will be more motivated, their curiosity will increase, and in the end, it will lead to obtaining satisfying learning outcomes (Irwanto et al., 2019; Sutarti \& Wibawa, 2018; Yupriyanti et al., 2015). Concrete media has positive benefits in teaching and learning activities, such as increasing interest in learning and motivating students to learn concepts (Sagitarini et al., 2020). So, concrete media can make it easier for students to know and practice studying to make learning feel more meaningful. Project Based Learning model assisted by concrete media is a learning model that invites students to carry out learning activities with project activities using the aids of real objects around students according to the learning material studied by students in the class. This study aims to determine the effect of a project-based learning model assisted by concrete media on the science knowledge competencies of fifth-grade students of SD Gugus I Kuta Selatan for the 2019/2020 academic year.

\section{Method}

The research to be carried out uses a quantitative research approach, using a quasi-experimental design. "Quasi experimental design is used because, in reality, it is difficult to get a control group to use for research" (Sugiyono, 2018). The research design used involved two sample groups. The two sample groups were given a 
pretest to determine that this sample group was equivalent using the t-test technique. If the two groups are equal, draw again to determine the experimental group and the control group. The experimental group was treated using a Project Based Learning model assisted by concrete media and a conventional control group. Then at the end of the study a post-test was given to the two sample groups. This study uses research samples taken from the population. The population of this study were all fifth-grade students of SD Gugus I Kuta Selatan for the 2019/2020 academic year, totalling 371 students consisting of 5 elementary schools with 13 classes, including SD No. 1 Benoa, SD No. 3 Benoa, SD No. 4 Benoa, SD No. 7 Benoa, and SD No. 9 Benoa. The sampling technique used in this study is random sampling. The method used is by drawing. The research sample was given a pretest. After that, the pretest data were tested for normality and a new homogeneity test. If the data were normally distributed and homogeneous, the equivalence test could be done using the t polled variant test. When the two samples are equal, the drawing is repeated from 2 equal samples to determine the school's name as the control group and the experimental group. This study's experimental group was class VB SD No. 9 Benoa and VA class SD No. 3 Benoa as the control group. Science knowledge competency data were collected using an objective test instrument in multiple-choice questions totaling 31 validated questions. Data analysis in this study used inferential statistics to analyze sample data, and the results were applied to the population. In this study, before testing the hypothesis analyzed by t-test, first measuring the analysis prerequisite test consists of the normality test and the homogeneity test of variance. The normality test is carried out to determine whether the data distribution is normally distributed or not. To calculate the normality test in this study using chi-squared. The variance homogeneity test is used to prove in the hypothesis test that this group experiences a difference arising from differences variance, not because of differences that occur due to differences in the group. The homogeneity test can be carried out if the two data groups are normally distributed. After the data has passed the prerequisite test, then it is continued with hypothesis testing using t-test analysis with the polled-variant formulat.

\section{Result and Discussion}

This study describes the average score, standard deviation, and variance of the post-test data on science knowledge competency. In this study, two data were obtained as follows: (1) the post-test data on the competence of science knowledge of students who took learning with the Project Based Learning model assisted by concrete media as an experimental group, and (2) the data on the results of the post-test on science knowledge competence of students who took conventional learning as a Control group. Based on the descriptive analysis, the students' science knowledge competency data obtained mean the experimental group $=81$, 44 while the control group $=70,33$. Before doing the t-test analysis, this data must be tested with prerequisite tests of normality and homogeneity tests. The normality test was analyzed by using the chi-square test with the criteria that if $x 2$ count $<x 2$ table with degrees of freedom $(\mathrm{dk})=(6-1)=5$, then the data distribution of the two groups is normally distributed. The data normality test was carried out using the Chi-square. The criterion for normality

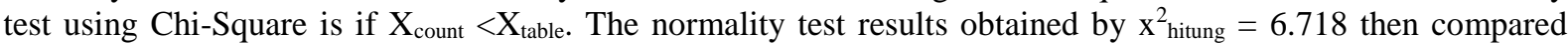
with $\mathrm{x}^{2}$ table $=11,07$. It shows that $\mathrm{x}^{2}{ }_{\text {hitung }}<\mathrm{x}^{2}$ table so that the experimental group data is normally distributed. In the control group compared the results of $\mathrm{x}^{2}$ hitung $=4.220$ with $\mathrm{x}_{\text {tabel }}^{2}=11.07$. It shows that $\mathrm{x}_{\text {count }}<\mathrm{x}_{\text {table }}^{2}$ so that the control group data is normally distributed. After the data were normally distributed, the variance homogeneity test was then carried out. Based on the data homogeneity test calculation, it was found that the score of Fcount $=1.09$. The homogeneity test of variants in this study used the $\mathrm{F}$ test at the $5 \%$ significance level with the numerator degrees of freedom $(\mathrm{n} 2-1)=(33-1)=32$ and the denominator degrees of freedom $(\mathrm{n} 1-1)$ $=(32-1)=31$ with the degree of freedom of the numerator $(\mathrm{n} 2-1)=32$ significance of $5 \%$, then obtained Ftable $=1.84$ thus the score of Fcount <Ftable, this means that the post-test scores for the control group (SD No.3 Benoa) and the experimental group (SD No.9 Benoa) were homogeneous. Based on the normality and homogeneity tests that have been carried out, it can be concluded that the results of research data come from normal and homogeneous data distribution so that the Hypothesis test can be carried out. Hypothesis testing The statistical analysis used in this study is testing the hypothesis is the mean difference test ( $\mathrm{t}$ test) with the polled variance formula. The following is a recapitulation of the results of the t-test analysis from the study sample. From the recapitulation of the calculation results show if $\mathrm{t}$ count $=4.17$ and at $\mathrm{t}$ table $=2,000$ for $\mathrm{dk}=\mathrm{n} \_1+\mathrm{n} \_2$ $2=63$ with a significance level of $5 \%$. Based on the test criteria, because $t_{\text {count }}>t_{\text {table }}, H 0$ is rejected, and Ha is accepted. So it can be concluded that there is a significant difference in the Natural Science Competency of the groups taught using the Project Based Learning Model assisted by concrete media with the groups taught conventionally by the fifth-grade students of SD Group I South Kuta for the 2019/2020 academic year.

Based on the results of the research that has been presented, it can be said that there is a significant difference in the Natural Science Competency of the groups taught using the Project Based Learning Model assisted by concrete media with groups taught conventionally by fifth-grade students of SD Group I South Kuta for the 2019/2020 academic year. The collaboration between the Project Based Learning Model and concrete 
media will allow students to learn more actively and make learning more meaningful. Meaningful learning allows students to learn on their own and build their knowledge. With this collaboration of models and media, students will get a better experience. The Project Based Learning (PjBL) model requires students' skills in arranging activity in the learning process that can make students investigate independently. In its implementation, the teacher continues to monitor students' development in learning activities in the classroom (Trianto, 2010). Project Based Learning students can learn independently and be directly involved who play an active role in solving problems (Sukawirya et al., 2017; Triningsih \& Mawardi, 2020). Project-Based Learning is a learning method that uses a learning medium and is assessed following government regulations. Students must carry out exploration, assessment, interpretation, synthesis, and information to produce various learning results (Pratama \& Prastyaningrum, 2016). Educators only act as facilitators. The focus of the PjBL model lies in student activities to unify learning resources and use them in realizing useful things but still following the curriculum set by the teacher, inviting students to explore and carry out evaluations so that they get results that are in line with expectations based on facts in the field (Hosnan, 2014; Kosasih, 2014) The implementation of this model begins with a problem and students collaborate on sources of knowledge to solve existing problems. The PjBL model makes student-centred learning and activities carried out by collaborating with groups to complete projects according to the design that has been made at the design stage (Jagantara, 2014). The Project Based Learning model invites students to make decisions, find solutions to a problem, and practice a responsible attitude towards something that must be done (Anggreni et al., 2020). The benefits obtained from using this model result in students studying the learning resources obtained and pour their creativity into a work that is following the material received (Kristiyanto, 2020). The project-based learning model is a process of doing a project using information obtained and useful for their lives, which still refers to the curriculum's basic competencies. In its implementation, the Project Based Learning model can be assisted by concrete media.

Concrete media is a learning resource that specifically displays real objects in terms of size, sound, movements, surfaces, weights and their benefits to facilitate the learning process (Suwitri et al., 2013). The use of concrete media is believed to help teachers convey learning messages easily so that students can master these learning messages quickly and accurately (Siti \& Wardani, 2017). With concrete media, students will be more motivated, their curiosity will increase, and in the end, it will lead to obtaining satisfying learning outcomes (Irwanto et al., 2019; Sutarti \& Wibawa, 2018; Yupriyanti et al., 2015). Concrete media has positive benefits in teaching and learning activities, such as increasing interest in learning and motivating students to learn concepts (Sagitarini et al., 2020). So, concrete media can make it easier for students to know and practice studying to make learning feel more meaningful to students.

This study's results are supported by the results of research conducted by Santiani et al., (2017). The results showed differences in science learning outcomes between fifth grade elementary school students who were taught with the Problem Bassed Learning model assisted by concrete media and fifth grade elementary school students who were taught with teacher-centered learning (tcount $=3.62$; ttabel $=2.02$ ). So the Problem Based Learning model assisted by concrete media has a positive effect on science learning outcomes. Research conducted by Diah Ratna Sari et al., (2018) shows that there is a significant influence on the competency of the science knowledge of the groups taught through the Guided Inquiry learning model assisted by Concrete Media with groups of students who are taught through conventional learning in fourth-grade students of SD Gugus Dewi Sartika, East Denpasar, 2017/2018 academic year. Research conducted by Sumarni, (2020) shows that the project based learning model is very helpful for students in increasing activities and achieving better learning outcomes. There are significant student learning outcomes compared to students' learning outcomes before using the project-based learning model. Research conducted by Rahmazatullaili et al., (2017) shows that (1) Students' creative thinking skills after learning with a project based learning model are better than before implementation. (2) The problem-solving ability of students after learning with the Project Based Learning model is better than before implementation. (3) The ability to think creatively has a positive influence on problem solving abilities.

Project Based Learning model assisted by concrete media is a learning model that invites students to carry out learning activities with project activities using the aids of real objects around students according to the learning material studied by students in the class. Project Based Learning model assisted by concrete media is an innovation that can be used to change students' mindset towards classroom learning to run more optimally according to expectations. Besides that, concrete media can give the impression that it is hard to forget to feel their benefits.

\section{Conclusion}

Based on the research carried out, it can be concluded that there is a significant effect of the Project Based Learning model assisted by concrete media on the competence of scientific knowledge of students of SD Gugus I Kuta Selatan class 2019/2020 academic year. Project Based Learning Model assisted with concrete media is a learning model that invites students to carry out learning activities with project activities using real 
objects around students following students' learning material. This learning increases interest in learning and motivates students to learn the concepts that are being given.

\section{References}

Adnyani, N. K. M., Pudjawan, K., \& Japa, I. G. N. (2020). Motivasi dan Hasil Belajar IPA dalam Pembelajaran Scramble Berbantuan Kartu Pertanyaan. Jurnal Ilmiah Sekolah Dasar, 4(2), 270. https://doi.org/10.23887/jisd.v4i2.25622

Anggreni, L. D., Jampel, I. N., \& Diputra, K. . (2020). Pengaruh Model Project Based Learning Berbantuan Penilaian Portofolio Terhadap Literasi Sains. Mimbar Ilmu, 25(1), 41. https://doi.org/10.23887/mi.v25i1.24475

Bahari, N. K. I., Darsana, I. W., \& Putra, D. K. N. S. (2018). Pengaruh Model Discovery Learning Berbantuan Media Lingkungan Alam Sekitar terhadap Hasil Belajar IPA. Jurnal Ilmiah Sekolah Dasar, 2(2), 103. https://doi.org/10.23887/jisd.v2i2.15488

Diah Ratna Sari, K. A., Ngurah Wiyasa, K., \& Ganing, N. N. (2018). Pengaruh Model Pembelajaran Inkuiri Terbimbing Berbantuan Media Konkret Terhadap Kompetensi Pengetahuan Ipa. Mimbar Ilmu, 23(2), 162-169. https://doi.org/10.23887/mi.v23i2.16416

Hosnan, M. (2014). Pendekatan saintifik dan kontekstual dalam pembelajaran abad 21. In kunci sukses implementasi kurikulum 2013.

Irwanto, Wasitohadi, \& Rahayu, T. S. (2019). Penerapan Pendekatan Scientific dengan Menggunakan Media Konkret untuk Meningkatkan Hasil Belajar Matematika Siswa Kelas 4 SD Irwanto1,. Jurnal Riset Teknologi Dan Inovasi Pendidikan Belajar Matematika, 2(1), 102-112. https://journal-litbangrekarta.co.id/index.php/jartika/article/view/174

Kosasih. (2014). No Title. In Strategi Belajar Dan Pembelajaran.

Panjaitan, S. (2017). Meningkatkan Hasil Belajar Ipa Melalui Media Gambar Pada Siswa Kelas Iia Sdn 78 Pekanbaru. Primary: Jurnal Pendidikan Guru Sekolah Dasar, 6(1), 252. https://doi.org/10.33578/jpfkip.v6i1.4105

Pratama, H., \& Prastyaningrum, I. (2016). Pengaruh model pembelajaran project based learning berbantuan media pembelajaran pembangkit listrik tenaga mikhrohidro terhadap kemampuan kritis. Jurnal Penelitian Fisika Dan Aplikasinya (JPFA)- Unesa, 6(2), 44-50. https://doi.org/http://dx.doi.org/10.26740/jpfa.v6n2.p44-50

Purwandari, N. A., Suardika, I. W. R., \& Putra, I. (2014). Model Experiential Learning Bernuansa VAK ( Visual , Auditori , Kinestetik ) Berpengaruh Terhadap Hasil. Mimbar PGSD, 2(1). https://ejournal.undiksha.ac.id/index.php/JJPGSD/article/view/3007

Raharjo, W. T., \& Kristin, F. (2019). Peningkatan Hasil Belajar Ipa Peserta Didik Menggunakan Model Pembelajaran Make a Match Pada Kelas 4 Sd. Satya Widya, 35(2), 168-175. https://doi.org/10.24246/j.sw.2019.v35.i2.p168-175

Rahmazatullaili, R., Zubainur, C. M., \& Munzir, S. (2017). Kemampuan berpikir kreatif dan pemecahan masalah siswa melalui penerapan model project based learning. Beta Jurnal Tadris Matematika, 10(2), 166-183. https://doi.org/10.20414/betajtm.v10i2.104

Rizwan. (2016). Meningkatkan Aktivitas dan Hasil Belajar Peserta Didik dalam Belajar IPA melalui Pembelajaran Konstektual. Jurnal Pendidikan, $2(1), \quad$ 11-20. https://doi.org/http://dx.doi.org/10.29210/12016227

Sagitarini, N. M. D., Ardana, I. K., \& Asri, I. G. A. A. S. (2020). Model Experiential Learning Berbantuan Media Konkret Berpengaruh Terhadap Kompetensi Pengetahuan Ipa. Jipp, 4(2). https://doi.org/http://dx.doi.org/10.23887/jipp.v4i2.26432

Samatowa, U. (2016). Pembelajaran IPA di Sekolah Dasar. Indeks.

Santiani, N. W., Sudana, D. N., \& Tastra, I. D. K. (2017). Pengaruh Model PBL Berbantuan Media Konkret terhadap Hasil Belajar IPA Siswa Kelas V SD. Mimbar PGSD, 5(2), 1-11. https://doi.org/http://dx.doi.org/10.23887/jjpgsd.v5i2.10826 
Siti, W., \& Wardani, K. W. (2017). Penerapan Pendekatan Scientific dengan Menggunakan Media Konkret untuk Meningkatkan Hasil Belajar Matematika Siswa Kelas 4 SD. Jartika, 1(5), 99-108. https://ejurnalmitrapendidikan.com/index.php/e-jmp/article/view/113

Sugiyono. (2018). Metode Penelitian Kuantitatif, Kualitatif, dan $R \&$ D. Alfabeta.

Sukawirya, G. B., Arthana, I. K. R., \& Sugihartini, N. (2017). Pengembangan E-Modul pada Mata Pelajaran Pemrograman Pernagkat Bergerak Kelas XII Rekayasa Perangkat Lunak Berbasis Project Based Learning Di Smk Negeri 2 Tabanan. https://doi.org/http://dx.doi.org/10.23887/karmapati.v6i1.9566

Sumarni, I. (2020). Penerapan Model Project Based Learning Untuk Meningkatkan Aktivitas Dan Hasil Belajar Siswa Dalam Mata Pelajaran IPA Tentang Sifat-sifat Cahaya Di Kelas V A Semester II Bagi Siswa SD Negeri Bantarkemang 1 Tahun Ajaran 2017/2018. Jurnal Teknologi Pendidikan, 9(1). https://doi.org/http://dx.doi.org/10.32832/tek.pend.v9i1.2764

Sutarti, N. P. S. E., \& Wibawa, I. M. C. (2018). Penerapan Model Pembelajaran Inkuiri Berbantuan Media Konkret Untuk Meningkatkan Hasil Belajar Muatan Pelajaran Matematika. Journal of Education Action Research, 2(4), 295. https://doi.org/10.23887/jear.v2i4.16319

Suwitri, N. P. D., Ardana, I. K., \& Negara, I. G. A. O. (2013). Pengaruh Pembelajaran Mind Mapping Berbantuan Media Konkret Terhadap Hasil Belajar IPA Siswa Kelas V SD Gugus III Banjar Anyar Kediri. Mimbar PGSD, 1(1). https://doi.org/http://dx.doi.org/10.23887/jjpgsd.v1i1.1251

Tarwiti, C. (2018). Pengembangan Media Kotak Ajaib Pada Mata Pelajaran IPA Materi Pesawat Sederhana Siswa Kelas V Sekolah Dasar. Jurnal Sekolah (JS), 2(9), 308-314. https://doi.org/10.1017/CBO9781107415324.004

Trianto. (2010). Pengantar Penelitian Pendidikan Bagi Pengembangan Dan Profesi Pendidikan Dan Tenaga Kependidikan. Kencana.

Triningsih, R., \& Mawardi. (2020). Efektivitas Problem Based Learning dan Project Based Learning Ditinjau dari Keterampilan Berpikir Kritis Siswa. Jurnal Riset Pendidikan Dasar, 03(April), 51-56. https://doi.org/https://doi.org/10.26618/jrpd.v3i1.3228

Yupriyanti, N. L., Suadnyana, I. N., \& Suniasih, N. W. (2015). Pengaruh Model Pembelajaran Generatif Berbantuan Media Konkret Terhadap Hasil Belajar Ipa Siswa Kelas V Sd Gugus 1 Manggis Kecamatan Manggis Kabupaten Karangasem Tahun Ajaran 2014/2015. MIMBAR PGSD Undiksha, 3(1). https://doi.org/10.23887/jjpgsd.v3i1.4825 